\title{
Rental tenure and rent burden: progress in interdisciplinary scholarship and pathways for geographical research
}

\author{
Madhuri Sharma (1) Mikhail Samarin 10
}

Accepted: 5 April 2021 / Published online: 15 April 2021

(C) The Author(s), under exclusive licence to Springer Nature B.V. 2021

\begin{abstract}
Rental housing accommodates more than a billion tenants worldwide, and in recent years, rentership has been increasing in some countries. Given reduced access to homeownership in various locations due to several causes, it is critical to focus on rentership which has received relatively less attention compared to homeownership, especially within the geography scholarship. In this review article, we identify four key themes that have naturally emerged from the close examination of recent interdisciplinary literature on rentership and rental affordability. These include: (1) rental housing financialization; (2) the proliferation of single-family rentals resulting from the U.S. foreclosure crisis; (3) the determinants and consequences of rent burden; and (4) the relationship between rent burden and regional economic specialization. We discuss these themes and propose potential opportunities for the geographic analysis of rent burden, its determinants, and their relationships with regional economic specialization. We posit that the four identified themes have been developing in apparent isolation, thus making scholarship less consistent. Moreover, research on rent burden is disjointed
\end{abstract}

M. Sharma $(\bowtie) \cdot$ M. Samarin

Department of Geography, University of Tennessee, 416

Burchfiel Geography Building, 1000 Phillip Fulmer Way,

Knoxville, TN 37996, USA

e-mail:msharma3@utk.edu

M. Samarin

e-mail: msamari1@vols.utk.edu in itself, which makes it difficult to establish a unified narrative and interlinked subthemes within the rent burden literature. Nonetheless, we contextualize the four themes in their application to geography and frame our discussion around the central notion of this article-rent burden.

Keywords Rental housing $\cdot$ Rent burden $\cdot$ Rental affordability · Urban geography · Financialization

\section{Introduction}

Rentals around the globe accommodate about 1.2 billion people (Gilbert, 2016). This is quite high given that in many countries, rental tenure has been declining since the mid-twentieth century due to a pervasive bias against rentership and disproportionate favoritism toward homeownership (Arnott, 2008; Colburn \& Allen, 2018; Elmelech, 2004; Landis \& McClure, 2010; Radzimski, 2014; Rakodi, 1995). There is also a widespread notion of homeownership as being superior (Fields, 2017; Rolnik, 2013) or normalized housing tenure (McKee, 2012). Such preoccupation with homeownership in several countries poses a threat to the availability and affordability of rental housing. For example, in Amsterdam, the Netherlands, the expansion of homeownership in existing neighborhoods tends to be accompanied by a reduction in 
affordable rentals (Hochstenbach, 2017). Only few nations (i.e., Germany, Switzerland, and to a lesser extent Austria) remain predominantly or almost renter societies (Beer \& Wagner, 2012; Bourassa et al., 2010; Soederberg, 2018; Steinführer \& Haase, 2009). However, declining rentership in some countries have changed during the last decades (Australia, Beer, 1999; the UK, Houston \& Sissons, 2012), especially after the Great Recession, and rental tenure has increased (China, Liu et al., 2020; Australia, Liu et al., 2016; the U.S., Immergluck, 2018; Wachter, 2015). Given the mentioned trends in certain locations, research on declining rental affordability and increasing rent burden is especially timely.

A geographical perspective is important when studying rental housing since acute housing problems (e.g., low affordability, high rent burden) generally depend on local contexts that need localized investigations (Bogdon \& Can, 1997; Quercia et al., 2002). Bunting et al. (2004, p. 361) claimed, "Most existing research dealing with housing affordability issues remains aspatial and does not indicate where the greatest affordability problems can be expected to be." This statement holds true even after almost two decades. Although Lee and Myers (2003) focused on homeownership, they argued that housing research should be sensitive to spatiality given its significant role in housing markets. Recently, Chen et al. (2016) and $\mathrm{Hu}$ et al. (2019) have highlighted the importance and utility of advanced geospatial techniques and novel data types for studying rental housing.

In this review, we re-emphasize the critical role of spatiality in rental markets as well as rentership and rent burden. In a world where rental housing has been increasingly converted into an investment asset (discussed in "Rental housing financialization" and "Rise in single-family rentals in the U.S." sections), the academic contribution to studying rentership through a geographical lens seems quite modest. There are some positive trends, nevertheless, when it comes to geographers' focus on general housing issues. For example, Bonds (2019) emphasizes geographers' renewed research on residential property in recent years, even though most of them concern homeownership. This narrative around superiority of homeownership applies to a broader context within the developed and the developing world (Cadstedt, 2010; Datta \& Jones, 2001; Kumar, 2011). Even the newly evolving notion of housing as a right focuses primarily on ownership rather than rentership, which makes one wonder if at all there exists any right to rentership if homeownership becomes inaccessible due to various reasons?

This review article concisely summarizes the literature pertaining to recent trends in rental housing markets in four sections. ${ }^{1}$ The first two emphasize the expanding conversion or rental housing into an investment asset which stems from (1) housing financialization across the globe, and (2) a rise in single-family rentals in the U.S. After situating these two thematic contexts in contemporary housing markets, we then provide (3) an overview of major subthemes within the rent burden scholarship dealing with measuring its extent, determinants, and consequences. Finally, we demonstrate (4) the importance of regional economic specialization and labor markets with regard to rental housing. Arguably, this last topic has been understudied by social scientists in general and geographers in particular. While summarizing recent progress along these four themes of scholarship, we discuss the gaps in the literature and offer potential avenues for future geographical research on rental housing markets and rent burden. Also, the four major themes ${ }^{2}$ on rental housing comprise their own fields of expertise and thus overlap each other only slightly. Nevertheless, we provide a common thread throughout our review that adds consistency and coherency to this manuscript.

\section{Rental housing financialization}

This section outlines the contemporary situation in real estate markets across the world and the broader

\footnotetext{
1 The sections/topics were not created artificially or selected randomly; instead, they formed rather naturally as a result of thematic grouping of the reviewed literature on rentership and rent burden. Prior to that division into sections/topics, a large array of relevant scholarly work had been accumulating for a 16-month period (April 2019-July 2020). In other words, the topics appeared only after an initial review of the selected literature (the keywords for searching articles were rent burden, rental housing, rentership, rental affordability and their combinations with such words as geography, geographical, spatiality, and spatial). To our knowledge, this classification by topics is not present (and reviewed) in other scholarly work in general and geography in particular.

2 The themes are also interchangeably called topics, scholarships, literatures, and sections of this article.
} 
contexts for the rent burden-related issues that are discussed in "Rent burden, its determinants and consequences" and "Regional economic specialization and rent burden" sections.

\section{Definition}

An important framework for studying contemporary housing markets is financialization-the process of converting real estate into "an asset class through a range of regulatory and socio-technical changes and constructions" (Aalbers, 2020, p. 595). Scholars suggest manifold signs of commodification of housing (Rolnik, 2013) followed by housing financialization (Aalbers, 2017; Fields, 2015, 2017; Waldron, 2018; Wijburg, 2020; Wijburg et al., 2018) in a neoliberal setting. One of those is the rapid transformation of housing into an investment asset in advanced economies and increasingly in the Global South (Aalbers, 2020; Fernandez \& Aalbers, 2020; Kutz \& Lenhardt, 2016). Moreover, housing is an important object of financialization (Aalbers, 2017), and since the beginning of the 2010s, rental housing financialization has become a leading framework for understanding major trends in modern rental housing markets (Wijburg, 2020).

Although studies on housing financialization have focused primarily on homeownership, over recent years, rental housing has become a frontier for financialization (Fields, 2017) following increased rental demands across various locations. Aalbers (2020) suggests that both public and private rental housing experience extensive financialization since rental housing is increasingly being viewed as an investment, contributing toward a spillover from mortgage debt financialization to the financialization of rental properties.

\section{Geographical research on financialization}

Despite the novelty of this scholarship, there are numerous empirical analyses concerning housing financialization in general (Kutz \& Lenhardt, 2016; Migozzi, 2020; Sanfelici and Halbert, 2019; Waldron, 2018) and rental housing financialization in particular (Aalbers et al., 2017; August, 2020; August \& Walks, 2018; Byrne, 2020; Crosby, 2020; Fields, 2017; Fields \& Uffer, 2016; Teresa, 2016; Wijburg et al., 2018). Below is a discussion about (a) the geographical coverage within this scholarship (with some other findings) and (b) the expansion of financialization to the developing world.

The scholarship on rental housing financialization mainly focuses on Germany and the Netherlands in Europe and New York in North America (e.g., Aalbers, 2017; Aalbers et al., 2017; Fields, 2015, 2017; Teresa, 2016; Unger, 2016; Wijburg et al., 2018). Some papers have compared the two (see Fields \& Uffer, 2016 contrasting rental housing financialization in New York and Berlin). Housing financialization research focusing on some European countries (Aalbers et al., 2017; Byrne, 2020; Unger, 2016; Waldron, 2018; Wijburg et al., 2018) have illustrated that financialization is especially acute there. For example, Germany has faced large-scale financialization of mass rental housing since the start of the twenty-first century when large quantities of public rental units were sold to private equity funds (Unger, 2016). Likewise, the Netherlands experienced extensive financialization of social housing providers (Aalbers et al., 2017). It happened because the Dutch housing associations managing the social housing stock had been gradually set apart from the government and had to find other financial sources. This led to financial losses and certain associations had to sell some housing units and increase rents in their properties.

Other relevant examples include Byrne (2020) who explored and compared rental housing financialization in the primarily homeownership societies of the UK, Ireland, and Spain. Additionally, there is a growing body of literature examining rental housing financialization in other countries/cities of the Global North such as Toronto (August \& Walks, 2018), Ottawa (Crosby, 2020), Canada (August, 2020), or Ireland (Waldron, 2018).

Wijburg et al. (2018) alluded that, despite being mostly an attribute of advanced economies, rental housing financialization had been becoming more ubiquitous. Thus, the emerging body of literature concentrates on housing financialization in the Global South because the phenomenon extends beyond the Global North (Aalbers, 2020), and empirical research on housing financialization manifested the Global South as its new frontier. Examples include Morocco (Kutz, 2018; Kutz \& Lenhardt, 2016), South Africa (Migozzi, 2020), and Brazil (Sanfelici \& Halbert, 2019), to name a few. Kutz and Lenhardt (2016) were 
among the first to expand the scholarly scope by exploring housing financialization in the Global South. Subsequently, Kutz (2018)'s study on Morocco emphasized the notion of unwillingness (discussed in "Contesting rental housing financialization" section) introduced by Fields (2017) who had examined active or passive refusal of financialization by renters. Kutz (2018) showed that residents' unwillingness to engage with the housing market had hindered housing financialization in Morocco.

Other empirical studies concentrating on the Global South offered insights for developing a theory pertaining to housing financialization. Sanfelici and Halbert (2019)'s analysis of Brazil demonstrated the importance of financialization to urban geography by linking the two and illustrated the close linkage between financial markets and the production and consumption of the urban built environment. Using this reasoning within the context of Cape Town, more recently Migozzi (2020) studied rental housing financialization spatially and connected urban and financial geography. He also challenged the notion of housing financialization as an exclusively Global North phenomenon. Fernandez and Aalbers (2020) offered a comparative framework to distinguish between housing financialization in the Global South and Global North. They further developed the idea of subordinate financialization in the Global South since it had been experiencing a different type of housing financialization caused by distinct mechanisms/factors. In short, rental housing financialization is gradually expanding geographically and the associated scholarship is keeping up with this contemporary process within the housing markets across various locations.

\section{Contesting rental housing financialization}

Emerging from the process of rental housing financialization is the notion of renters' movements and activism against financialization. This notion is exemplified by the studies of Teresa (2016) and Tapp (2019) who discuss the political struggles of renters in New York and Los Angeles respectively. Teresa (2016) explored rental housing financialization through the fictitious capital prism and showed that tenant activism was a result of the financialization of rentregulated housing in New York. By fictitious capital, Teresa meant financial resources lent in anticipation of future value. Thus, the case of New York demonstrated how low-income rental housing was negatively affected by owners' expectations of future value. This mix of precarious rentership (i.e., lowincome tenants) and predatory ownership (i.e., financialized landlords) instigated tenants' activism. Similarly, Tapp (2019) considered rental markets as an arena for new political fights, especially in locations such as Los Angeles with relatively low homeownership rates and a limited number of affordable rentals. Consequently, such revival of renters' movements against rental housing financialization occurred due to simultaneously increasing rentership and rental rates.

Likewise, Fields $(2015,2017)$ linked rental housing financialization and political struggle among tenants. Fields (2015)'s analysis of rental housing financialization in New York connected the ways community organizations and activists fought against such efforts. As mentioned in "Geographical research on financialization" section, Fields (2017) conceptualized tenants as unwilling subjects of rental housing financialization. This notion of unwillingness emphasizes that financialization is often met with defiance. Crosby (2020) further expanded this line of reasoning by challenging the narrative that rental housing financialization is inevitable or uncontested. In doing so, he examined the tactics of legal repression utilized by financialized landlords in reprisal for renters' resistance.

Based on the discussion above, tenants (in contrast to owners) have more struggle with financialization due to their apparent and larger precarity. Given the increased vulnerability of renters, we believe financialization should be considered a primary threat to rental housing affordability which also increases rent burden. To the best of our knowledge, this relationship between housing financialization and rent burden has not yet been explored both theoretically and empirically, and we hope to address this gap in the near future.

Financialization and gentrification

Another relatively established subtheme within the financialization literature is that of gentrification. The concept of gentrification often appears in the housing financialization scholarship because the two processes are sometimes intertwined (August, 2020; Crosby, 2020; Wijburg et al., 2018). For example, August and Walks (2018) emphasized the rise of a new, rental 
form of gentrification which is caused by rental housing financialization that eventually reduces the protection of renters and diminishes public housing supply. During this process, poorer renters are pushed out of inner-city areas into suburban neighborhoods. All these create a rental affordability crisis for lowand even middle-income tenants, whereas the investors extract profits from these same trends. Thus, rental housing financialization and the ensuing processes (i.e., financialized gentrification) may cause rising rent burden. However, as in the case of tenant's activism, this relationship has not been acknowledged in the current literature.

Additionally, there has emerged a notion of stateled gentrification that centers on one of the most financialization-affected cities-Amsterdam, the Netherlands. In this regard, Hochstenbach (2017) documented that housing policies influenced by market-oriented restructuring pushed gentrification in the high-demand neighborhoods of Amsterdam. Likewise, Savini et al. (2016) suggested that the long history of the state as a housing regulator allowed for state-led gentrification in Amsterdam's central neighborhoods.

Future directions and concluding remarks

Housing financialization is a rapidly growing body of literature, but there are some aspects of it that still deserve attention. Wijburg (2020, p. 4) broadened the research agenda by putting forward the concept of definancialization as "deleveraging the debt-fueled housing economy and undermining finance-led housing accumulation." Specifically, he offered three lines of research to advance the housing financialization scholarship. His suggestions include (1) designing financial market reforms for deconstructing housing accumulation caused by the financial sector, (2) examining policies aimed at expanding affordable housing, and (3) normalizing movements contesting rental housing financialization locally.

Regarding the relationship between geography and rental housing financialization, Waldron (2018) commented on the lack of spatiality in much of this scholarship. He stated that real estate financialization was not sufficiently studied in terms of critical geographic perspectives. By analyzing Dublin's real estate market and its geographies, Waldron made an effort to contribute to this apparent gap. Similarly,
August and Walks (2018) employed a geographical lens to study rental housing financialization in Toronto (see "Financialization and gentrification" section). There still exists room for more studies comparing financialization processes in disparate national contexts or cities across the world. It has been a while since Fields and Uffer (2016)'s call for more comparative research, but few have followed their suggestion. Another point of concern is that the rental housing financialization concept may seem arcane for those outside this subfield of economic geography.

Finally, despite being one of the major threats to rental affordability, it is almost impossible to use financialization as a conventional variable, since it is difficult to quantify it at the scales typically used in urban geography research. Another shortcoming of this literature is that it is seldom linked to the rent burden scholarship ("Rent burden, its determinants and consequences" and "Regional economic specialization and rent burden" sections). We suggest that the existing rental housing financialization literature neither refers to rent burden nor does it build upon other cognate (i.e., rental housing-related) scholarships. Nevertheless, providing this synopsis of rental housing financialization research is necessary in order to emphasize that this contemporary process may be potentially influencing rent burden and that the research studying the two simultaneously may be fruitful.

\section{Rise in single-family rentals in the U.S.}

An increase in single-family rentals (resulting from the foreclosure crisis) have recently stimulated heightened interest among institutional landlords/investors regarding this type of housing. Building on this momentum, there has formed a body of literature on these processes which have much in common with rental housing financialization. Hence, the following section focuses on single-family rentals in the U.S. and subsequent investor activity in housing markets. There are two reasons for concentrating on this: (a) the growing extent of single-family rentals has resulted in the emergence of this literature directly connected to rental housing; (b) the U.S. is the most frequent ${ }^{3}$ study

\footnotetext{
${ }^{3}$ There are several reasons why the U.S. is at the forefront of the rent burden research: large and diverse population; plenty of
} 
area in the rent burden scholarship which is reviewed in "Rent burden, its determinants and consequences" and "Regional economic specialization and rent burden" sections. Consequently, it is important to scrutinize the proliferation of such rentals since this trend (i.e., increasing rentership and ensuing activity of institutional investors) may be related to rent burden in one way or another.

\section{Repercussions of foreclosure crisis}

The recent U.S. foreclosure crisis has led to an extensive conversion of single-family homes into rentals (Chilton et al., 2018; Colburn et al., 2020; Fields et al., 2016; Immergluck, 2018; Immergluck \& Law, 2014a, 2014b; Pfeiffer \& Lucio, 2015; Pfeiffer et al., 2020). Since this crisis, there has been a pronounced tenure shift toward rentership in large U.S. metropolitan statistical areas (MSAs), and a substantial share of this increase concerns rental single-family homes (Immergluck, 2018), now accounting to more than one-third of all U.S. tenants residing in single-family rentals (Pfeiffer et al., 2020).

This foreclosure crisis further facilitated corporate investors' acquisition and leasing out of thousands of foreclosed homes all across the U.S. These firms created vast pools of institutionally owned singlefamily rentals (Colburn et al., 2020; Fields et al., 2016). This promoted extracting profits from real estate that were otherwise difficult to sell, given a decreased demand or financial abilities to owning homes. A reluctance to sell lower-priced single-family homes further led the firms to convert them into rentals in anticipation of future price appreciation. Demographic changes also contributed toward the proliferation of single-family rentals, given that the demand for rentals remained strong among the younger generation, especially those belonging to the recently graduated young adults with higher levels of outstanding college debts and delayed family formation (Pfeiffer et al., 2020). All these reasons cumulatively

\footnotetext{
Footnote 3 continued

room for geographical variations; intense research activity; data available at the granular levels, to name a few. We should additionally note that there may be a similar branch of knowledge, but in another language (we checked Russian in that regard and did not find any research effort on rent burden).
}

opened predominantly owner-occupied neighborhoods to renters.

This increased rentership, however, differs substantially from the pre-crisis situation wherein the number of single-family rentals had declined throughout the 1990s due to increased homeownership, lower interest rates, and expanded access to credit. Moreover, Immergluck and Law (2014b) theorized about the possibilities of declining homeownership among Americans because homeownership could have become less accessible for both low- and modestincome households. Hence, homeownership rates in the U.S. might soon be lower than those in the 1980s, given that Wachter (2015) found that since 2006 there has been an increase of 6-million new-renter households.

Geographical scope and spatial patterns

Concerning geographical variations, the metropolises with higher degrees of investor activity in terms of single-family rentals include those that experienced a significant decline in property values, causing a reluctance to sell homes at lower prices and an increased demand for rentals. Colburn et al. (2020) claimed that acquisitions by corporate investors predominantly concentrated in fast-growing regions most affected by the Great Recession, and where housing prices had declined significantly and increases in rentership had been more pronounced. Such areas are overrepresented in the Sunbelt and Immergluck (2018) demonstrated that it was the domain of single-family rentals, since nine MSAs with the largest increases in single-family rentals (2006-2015) were in that region. Given this spatial concentration, besides several empirical analyses of single-family rentals across the nation (Colburn et al., 2020; Pfeiffer et al., 2020), there are also those specifically focused on the Sunbelt MSAs such as Atlanta (Immergluck, 2018), Nashville (Chilton et al., 2018), and Phoenix (Pfeiffer \& Lucio, 2015).

Scholars have also suggested that the conversion of single-family homes into rentals has indeed widened the geography of opportunity for low-income renters by expanding their choice and by introducing them into well-off areas. This might have reversed the 1990s tendency when rentals were often concentrated in disadvantaged neighborhoods (Pfeiffer \& Lucio, 2015) mostly due to housing filtering and 
neighborhood change. Others, however, viewed the foreclosure crisis as a missed opportunity (Colburn et al., 2020) for appropriate entities to provide larger numbers of affordable rentals.

Despite the widening geography of housing opportunity, neighborhoods with substantial increases in single-family rentals tend to be less prosperous. For example, Immergluck (2018)'s analysis of Atlanta demonstrated that the neighborhoods with larger Asian, Hispanic, and African American communities experienced higher increases in single-family rentals. Likewise, Pfeiffer et al. (2020) found that neighborhoods with the highest growth of single-family rentals were more disadvantaged, racially/ethnically diverse, and had higher rates of child poverty.

Chilton et al. (2018)'s geographical analysis of rental housing financialization (following the logic offered by Waldron, 2018; "Future directions and concluding remarks" section) in Nashville MSA focused on the socio-spatial distribution of singlefamily rentals' real estate investment trusts (REITs). This study linked the two distinct scholarships on rather cognate topics-American single-family rentals and rental housing financialization. The authors tracked the dynamics after the Great Recession and showed that single-family rentals' REITs were more active in housing markets across the nation and exhibited some spatial concentrations in U.S. housing markets. Such concentrations include Nashville that has become one of the hotspots of single-family rentals' REITs. This analysis also demonstrated that rental housing financialization purposefully competed with homeownership and this further expanded rentership.

\section{Future prospects}

Although the increase in single-family rentals have arguably widened the geography of opportunity (see "Geographical scope and spatial patterns" section), scholars have theorized the potential outcomes of this increase, claiming a relatively unstable nature of such rentals. For example, Pfeiffer et al. (2020) noted the precarity of tenants residing in single-family rentals since such rentals' availability and new opportunities to live in better neighborhoods are subject to the reversal in the long-term. In other words, investors might change their behavior and re-convert singlefamily rentals into properties for sale. This vulnerability of tenants residing in single-family rentals is exacerbated by rigidity among policymakers in terms of tenure diversity, which also results in halfbaked policies and a lack of tenant protections (Wegmann et al., 2017).

Given the relatively unstable nature of singlefamily rentals (i.e., they can be re-converted from rentals), some scholars (Colburn et al., 2020) have also theorized the ongoing COVID-19 crisis, and if it would have similar consequences to those of the Great Recession which had facilitated the rise in singlefamily rentals and created opportunities for institutional landlords. It remains to be seen whether the pandemic will be a new recession helping singlefamily rentals to exist and thrive.

\section{Comparing two scholarships and concluding remarks}

Since single-family rentals have increasingly garnered attention of institutional landlords/investors, the two bodies of literature (the other is rental housing financialization) have something in common. However, as opposed to the scholarship on rental housing financialization ("Rental housing financialization" section), scholars studying single-family rentals tend to examine the topic spatially by using mapping techniques and quantitative methods (Chilton et al., 2018; Colburn et al., 2020; Immergluck, 2018; Pfeiffer \& Lucio, 2015). Additionally, much of the literature on single-family rentals focuses on proposing solutions for normalizing federal housing policies regarding single-family rentals. And yet, not much emphasis has been paid to empirically examining intrametropolitan geographical patterns of single-family rentals. Moreover, single-family rentals offer a novel opportunity for geographers that may contribute to a nuanced understanding of spatiotemporal features of such real estate assets.

Ultimately, it is important to acknowledge the differences in the built environment contexts in much of the U.S. (predominantly single-family homes) and Europe (multi-family apartments). This might be the reason for the apparent isolation of scholarships on rental housing financialization and single-family rentals. Decades of favoring the American Dream (in regards to housing this means single-family detached homes with sizeable land lots in suburban areas) since the WWII has made the U.S. distinct from much of 
Europe in terms of its built environment. Consequently, American scholars have studied increasing numbers of institutionally owned single-family rentals resulting from the foreclosure crisis, whereas European scholars have mostly dealt with rentals in apartment buildings in dense cities. Hence, rental housing financialization within the American context remains understudied (see Chilton et al., 2018) and not explicitly connected to declining affordability and increasing rent burden. Moreover, the scholarship on single-family rentals is not linked to rental housing financialization, and vice versa.

The remainder of this review article builds upon the delineated contexts of (1) the increased investor activity in contemporary housing markets which may pose a threat to or at least affect rental housing affordability; and (2) the growing number of renter households in the U.S. since it is a leading study area when it comes to examining rent burden (discussed in "Geographical scope and recent trends" section and explained in footnote 3 ).

\section{Rent burden, its determinants and consequences}

The previous two sections contextualized the contemporary situation in rental housing markets since the 2010s. This in-depth background (besides forming two distinct scholarships on rentership necessary to be reviewed in this article) is essential for the introduction and then in-depth understanding of "Rent burden, its determinants and consequences" and "Regional economic specialization and rent burden" sections focusing on rent burden. Interestingly, a majority of scholarship reviewed in this section also belong to the 2010s. Despite its apparent novelty, the term "rent burden" itself began to sporadically appear in the academic literature in the mid-1980s (Goodman \& Kawai, 1984) and the following decade (Oh, 1995). We argue that due to the ambiguity and inconsistency of this terminology, rent burden has not received the dissemination and attention it potentially could have gained. Rent burden was often called housing cost burden (Chi \& Laquatra, 1998; Deidda, 2015; DeVaney et al., 2004; McConnell \& Akresh, 2010; Mimura, 2008; Newman \& Holupka, 2014, 2015), thus having mixed meanings and often being overshadowed by homeownership, affordability burden (Moore \& Skaburskis, 2004; Withers, 1997), housing stress (discussed in "Geographical scope and recent trends" section), resident cost burden (Williamson, 2011), shelter burden (Withers, 1997), and shelter cost burden (Elmelech, 2004). Some have used the terms rent burden and housing cost burden interchangeably (Meltzer \& Schwartz, 2016). In the articles reviewed below, we illustrate how rent burden oftentimes has not been called by its name, even when this phenomenon was implied. Nevertheless, to the best of our knowledge, this review article contains an exhaustive digest of the rent burden literature.

Geographical scope and recent trends

Although rent burden articles have mostly focused on the U.S. (Colburn \& Allen, 2018; Gabriel \& Painter, 2020; McClure, 2005; Susin, 2007), there are some on Canada (Moore \& Skaburskis, 2004), European countries (Deidda, 2015; Germany, Backhaus et al., 2015; Austria, Beer \& Wagner, 2012), and the Philippines (Ballesteros, 2004). Interestingly, the scholarly work concentrating on Australia, but focusing specifically on housing stress (including rentership), has accumulated rather similar insights while somehow not accounting for the rent burden research conducted within North America. This is partly due to the usage of different terms for essentially the same phenomenon-housing stress instead of rent burden. Although housing stress is a similar concept, the two bodies of literature lack incorporation, with the Australian experience (Daniel et al., 2018; Liu et al., 2016; Rahman \& Harding, 2014; Tanton \& Phillips, 2013) not building upon the cognate scholarship. As such, the use of different terms for essentially the same phenomenon hinder the advancement of research on rent burden, since the American and the Australian contexts could have beneficially informed each other. Likewise, Liu et al. (2020)'s analysis of Chinese rental housing markets and affordability also used the word "stress." Bunting et al. (2004) examined the geography of rental housing affordability stress across Canadian metropolises. Thus, terminological incompatibility is quite problematic ${ }^{4}$ for scholars to discover and expand on each other's scholarship.

\footnotetext{
$\overline{4}$ This was also the case with the authors since the housing stress literature appeared in a much deeper stage of searching for rent burden articles.
} 
Regarding the American context, rent burden was first considered by the Department of Housing and Urban Development in 2003 (Susin, 2007). Since then, various entities have produced research reports (Aratani et al., 2011; Bean, 2012; Carpenter et al., 2018; Ellen \& Karfunkel, 2016; Leopold et al., 2015; Ray et al., 2014) that focused on measurement issues and estimated/projected trends of rent burden at the national or metropolitan levels (Charette et al., 2015; Immergluck et al., 2016).

During the Great Recession, rent burden among American renters did not increase (Colburn \& Allen, 2018). This situation, however, has then changed due to increased rentership ("Rise in single-family rentals in the U.S." section) and a reduced supply of lowincome housing ("Zoning and housing supply" section). Indeed, rent burden has become more widespread across the U.S. and its magnitude has been increasing since the Great Recession (ibid). Other scholars have also acknowledged and analyzed the aggravation of rent burden since the recession (Dawkins \& Jeon, 2018; Edmiston, 2016; Lens, 2018), and in 2015, almost a half of U.S. tenants paid more than $30 \%$ of their income on rent (Gabriel \& Painter, 2020). Thus, studying the issue of rent burden is crucial, especially holistically and from a geographic perspective across diverse settings, not only within the American context, but also across the world.

After providing an overview of major study areas in the rent burden literature (and recent trends in the U.S.), we now proceed to the various aspects of rent burden. In the remainder of this section, we summarize research with similar foci and identify prominent subthemes while emphasizing major findings from the rent burden literature. To our knowledge, this is a first effort to accumulate, summarize, and classify the rent burden scholarship while linking it to other themes reviewed earlier in this manuscript. In the following subsections, some articles appear throughout a number of subheadings since they may touch upon several facets ${ }^{5}$ of rent burden.

\footnotetext{
5 One aspect of rent burden (i.e., its relationship with local labor markets and their economic specialization) requires more thorough attention and that is why it has its own "Regional economic specialization and rent burden" section.
}

Defining rent burden

Scholars and policymakers generally agree that renters should spend less than $30 \%$ of their income on housing, and crossing this threshold would put them in the 'rent-burdened' category (Aratani et al., 2011; Bean, 2012). This $30 \%$ threshold is currently used by the U.S. government entities for assisting qualifying households (Joice, 2014). However, "overburdened" within the EU implies households spending more than $40 \%$ of their disposable income on housing costs/rent (Sunega \& Lux, 2016). Such use of fixed thresholds makes defining rent burden quite problematic. Therefore, assigning a certain percentage - the income-ratio approach-has been criticized by scholars because this might be an inefficient way of gauging affordability (Bramley, 2012). Fixed thresholds do not distinguish between local and regional differences since spending more than $30 \%$ on rent may be common in certain geographic areas (Metcalf, 2018). Moreover, Hulchanski (1995) long ago disagreed with any attempt to reduce housing affordability to a single percentage of income because of a failure to capture the reality of fundamental and obvious differences among households. Likewise, Kutty (2005) indicated that households may spend a higher percentage of income on housing, but still not feeling burdened. This may be indicative of their preferences for better quality and/or larger quantity of housing, and those preferences may not significantly affect other expenditures (Coley et al., 2014). Bramley (2012), however, concluded that conventional thresholds are still the best objective measure, but they could be supplemented by residual income ratios.

Housing-induced poverty and income inequality

Based on the issues concerning defining rent burden as a fixed threshold, there emerges another aspect related to the residual spending in renter households. Clearly, renters adjust their household budgets to rent increases, income decreases, or job losses by cutting down on other expenditures. A higher share of household's expenses on housing may also provoke housing-induced poverty-a reduced consumption of other goods/services (i.e., food, healthcare, education). Thus, housing-induced poverty, a term coined by Kutty (2005), is an outcome of overspending on housing that leaves families with fewer available 
resources for other expenditures (Oh, 1995). Concerning some empirical findings, Kutty (2005) demonstrated that housing-induced poverty was largely concentrated in the MSAs in the U.S. West and Northeast. Further, Elmelech (2004) documented that new immigrants in New York faced severe shelter-cost burden that left them with little financial resources to spend on other necessities. Meltzer and Schwartz (2016) illustrated housing-induced poverty among New York's tenants wherein higher rent burden was associated with worse self-reported health and healthcare postponement.

Rent burden also reduces savings - the key element of asset accumulation (Mendenhall et al., 2014). Deidda (2015)'s analysis of five European countries demonstrated that higher housing costs might reduce other expenditures which eventually may lower households' standard of living. She also highlighted the importance of tenure-homeowners were less likely to report subjective poverty. In the Australian context, Tanton and Phillips (2013, p. 108) alluded to housing-induced poverty and commented on fixed thresholds: "...it is not really whether a low-income household is spending more than $30 \%$ of their income on housing costs; it is how much over $30 \%$ of their income is being spent on housing costs that affects how much they have left over to purchase...other necessities."

Finally, income inequality also has a role in affecting rental affordability (Dong, 2018; Matlack \& Vigdor, 2008). That is, higher income inequality tends to associate with the greater magnitude of rent burden across U.S. MSAs since inequality decreases affordability for the poor, and the presence of higherincome groups inflates housing prices and reduces housing options for low-income groups (Matlack \& Vigdor, 2008). Dong (2018) confirmed that income inequality had a significant effect on rental affordability and rent burden, since higher Gini coefficients (less equality) associated with a rise in rent-burdened households.

\section{Children's development and life course}

Logically stemming from housing-induced poverty is the scholarship on children's development. In 2009 , about $54 \%$ of renter-occupied households with children in the U.S. were burdened (Aratani et al., 2011). Newman and Holupka (2014) demonstrated that funds available for children's enrichment were the lowest when a household spends a large fraction of income on housing costs. Besides, children's enrichment was also low among households with a smaller percentage of income spent on housing, but housing quality in such households was inadequate. This alludes to the notion that some households technically avoid being rentburdened while greatly sacrificing other essential characteristics (i.e., housing and/or neighborhood quality).

Indeed, there is often a tradeoff among low-income households when it comes to choosing between three dimensions-housing problems, neighborhood disorder, and housing costs (Coley et al., 2014; Meltzer \& Schwartz, 2016). Coley et al. (2014) identified four different profiles of low-income families. For example, some families preferred being overburdened but living in relatively good neighborhoods and thus having better outcomes for children (this further accentuates the problem of defining rent burden which is discussed in "Defining rent burden" section). Consistent with this, Leventhal and Newman (2010, p. 1168) stated, "The benefits of living in a community with excellent schools, low crime rates...that support healthy child development mitigate or even overwhelm the negative effects of the stress on families of a high housing cost burden."

Given how children's development and rent burden are intertwined, a stage within the life course may also predict rent burden's extent (Moore \& Skaburskis, 2004), with older people at lower risk than the younger ones (Chi \& Laquatra, 1998; Tanton \& Phillips, 2013). DeVaney et al. (2004) suggested that for both renters and owners housing cost burden was higher for single and single-parent households compared to childless couples. Colburn and Allen (2018) confirmed that larger households and households with children were more likely to be rent-burdened. Housing cost burden might also affect the life cycle itself. As shown by Nelson et al. (2013), housing cost burden ${ }^{6}$ had a negative association with marital satisfaction after controlling for age, income, education, and race/ ethnicity, whereas households with a fully repaid mortgage had higher levels of marital satisfaction.

\footnotetext{
${ }^{6}$ Those authors only consider ownership but their finding is worthwhile to mention here.
} 
Race/ethnicity and immigration

In the American context, race/ethnicity is commonly included in studies as a predictor of rent burden (Colburn \& Allen, 2018; McConnell, 2013; Susin, 2007; Withers, 1997). Generally, families headed by people of Hispanic, Asian, and Native American descent were more likely to experience rent burden than whites (DeVaney et al., 2004). Black and Hispanic households were the most affected by evictions resulting from rent burden (Desmond, 2018), and low-income Blacks experienced rent burden at disproportionally higher rates than lowincome whites and Hispanics (Mimura, 2008).

Immigration had a small impact on the increase of housing prices/rents and little effect on housing outcomes for native renters (Greulich et al., 2004). However, studies focusing on immigrants themselves have documented their rent burden and substantial struggles (Salinas \& Teixeira, 2020). For example, Elmelech (2004) concluded that new immigrants experienced economic hardships due to higher housing cost burden coupled with shortages in affordable housing during large-scale migration. Immigrants coming to the U.S. from developing countries had substantially higher housing cost burden than those from Western Europe mostly due to lower education and English proficiency, and a lesser degree of assimilation (McConnell \& Akresh, 2010), along with factors such as immigrants' human capital resources and stage in the life course (DeVaney et al., 2004). McConnell (2013) also found that immigrants' legal status was important, since there were large disparities between undocumented versus documented Latino immigrants, U.S. born Latinos, whites, and African Americans. In Los Angeles, specifically, immigrants' legal status better predicted housing affordability problems among low-income households than their race/nativity.

\section{Zoning and housing supply}

By the late twentieth century, housing quality and the related financing had improved substantially which indirectly coerced low-income families into paying higher shares of their income toward housing (Malpezzi \& Green, 1996; Turk, 2004). Besides improved quality of housing, scholars have attributed increased rent burden to macro-trends in housing construction wherein rent burden is generally exacerbated by the inadequate supply of low-income housing (Turk, 2004; Yates \& Wulff, 2005). This is exemplified by the U.S. that experienced a reduced supply of low-cost and affordable rental units (Collinson, 2011; Gabriel \& Painter, 2020; Immergluck et al., 2018). Additionally, there were other difficulties in preserving small, low-income rentals such as landlords' reluctance to keep rental housing affordable and large property owners' dubious behavior toward low-end housing (Garboden \& Newman, 2012).

In large American cities, high construction costs and a lack of developable land hinder the construction of affordable and market-rate rental housing (Landis $\&$ McClure, 2010). In contrast, there are places with abundant developable sites, less restrictive regulations, and lower/negative rates of household growth which contribute toward a sufficient supply of affordable rentals (ibid). Correspondingly, Glaeser and Gyourko (2002) documented that in much of America, housing prices were close to the prime cost of new construction, except in cases of California and several East Coast cities where zoning was the primary cause for significant differences between construction costs and housing prices.

Regarding zoning restrictions, Beitel (2007)'s study on San Francisco found no evidence for strict zoning being the primary factor inflating housing prices/rents; instead, market dynamics and household search behavior were responsible for the construction of high-end housing. However, zoning in some suburban communities may be used to indirectly raise housing costs and screen out the socioeconomically undesirable who cost the community more than they generate in tax revenues (Stockman, 1992). Additionally, some suburbs routinely prohibit the construction of low-cost rentals (Koebel, 1997) by employing large-lot requirements or density controls. Such strict land use regulations on rental housing in suburbs reduce the supply of multifamily rentals and simultaneously increase the average size of new housing (Schuetz, 2009). Yet another issue is NIMBY (not-inmy-backyard) attitudes (Scally, 2013) that limit the construction of affordable rentals in specific neighborhoods/municipalities. All these cumulatively diminish mobility among low-income households and concentrate them in inner-city areas. 
Geographical patterns and mobility

This subtheme discusses the significant opportunities for timely geographical inquiry into rent burden. Existing research suggests that the geography of rentburdened households within metropolitan areas might not follow a typical North American pattern when only inner-city areas are being affected. A study of select Canadian metropolitan areas (Bunting et al., 2004) found that inner suburbs had a higher incidence of households with affordability stress ${ }^{7}$ than expected. Rahman and Harding (2014) examined housing stress across Australia and found that every ninth household experienced it, and private renter households were the most affected by housing stress. Such households concentrated in the capital cities of six states and two internal territories.

Regarding mobility, rent burden sometimes leads to evictions, repeat relocations, forced displacement toward disadvantaged, crime-ridden areas, and coresiding with friends or relatives (Desmond \& Shollenberger, 2015). African Americans, the young, and women tend to change their rental housing more frequently (Teater, 2009). This forced mobility may mask the real extent of rent burden in a particular location because tenants paying unbearable rents may change their housing and relocate to more affordable areas, often compromising with neighborhood quality. In Australia, housing affordability was the primary cause for forcing people toward disadvantaged areas (Baker et al., 2016), which created concentrations of 'at-risk households' in such locations.

\section{Rent burden in welfare programs}

American scholars have examined rent burden among renters in low-income housing tax credit (LIHTC) units (O'Regan \& Horn, 2013; Williamson, 2011), participants in the housing choice voucher program, HCVP (Dawkins \& Jeon, 2018; Mast, 2014; McClure, 2005), or both (Lens, 2018). For example, O'Regan and Horn (2013) considered LIHTC renters in 18 states and concluded that the program helped its tenants to reduce rent burden relative to people with comparable incomes. Although program-focused articles are not about geography and form their own

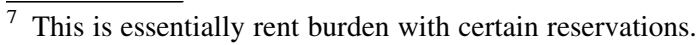

policy-related scholarship, ${ }^{8}$ McClure (2005) found that the American South was the most problematic region (i.e., it had the highest rent burden among HCVP participants) because of lower welfare levels in the region.

Summary and concluding remarks

This exhaustive scholarly review indicates a rather apparent lack of geographically-focused research on rent burden. Although all the articles reviewed in this section are undoubtedly worthwhile, some of them focused mostly on affordability, housing cost burden, low-income housing, or a single aspect of rent burden. Several summarized articles tangentially referred to rent burden without examining it holistically. For example, a number of aspatial studies focused on certain aspects of housing cost burden such as children's development (Coley et al., 2014; Leventhal \& Newman, 2010; Newman \& Holupka, 2015), family structure (DeVaney et al., 2004), marital satisfaction (Nelson et al., 2013), or savings behavior (Mendenhall et al., 2014). However, these studies did not emphasize rentership (or they concentrated only on owners). Some studies with geographical insights analyzed owners and renters together and focused on specific facets such as housing-induced poverty in select EU countries (Deidda, 2015) or immigrants in U.S. cities (Elmelech, 2004; McConnell, 2013). Few scholarly works have examined renters specifically and rent burden in connection with immigration (Greulich et al., 2004), income inequality (Matlack \& Vigdor, 2008) across U.S. MSAs, health issues in New York (Meltzer \& Schwartz, 2016), or diminished abilities of rent-burdened households to afford other items (Oh, 1995).

Recent research has focused mostly on calculating rent burden's extent and dynamics by utilizing households from surveys (Colburn \& Allen, 2018; Eggers, 2010; Susin, 2007) or welfare programs (see "Rent burden in welfare programs" section). Comparative studies examining cities/MSAs and intra-urban patterns are scanty. Same is the case with comprehensive studies explicitly analyzing rent burden determinants through a geographic lens (see Bunting et al., 2004;

\footnotetext{
8 That is why we only provide a synopsis of the current progress in this policy area without delving into much detail about those welfare programs.
} 
Liu et al., 2020). Most reviewed articles have focused on a single aspect/determinant (i.e., race/ethnicity, income inequality, family structure, or health), have lacked geographic focus, and have emphasized rentership only occasionally. Other studies and research reports have outlined basic temporal/spatial trends without delving into rent burden determinants-an area needing immediate attention. Despite a substantial number of scholarly works reviewed here, there is plenty of room for more generalizable knowledge and a nuanced understanding of rent burden from a geographical perspective.

\section{Regional economic specialization and rent burden}

Although this theme may be viewed as a logical continuation of "Rent burden, its determinants and consequences" section, it nevertheless deserves its special discussion owing to the integral role of labor markets and their regional economic specializations in influencing housing markets and rent burden.

Relationships between housing, economic growth, and labor markets

Regional labor markets, their economic specialization, and economic growth may play a crucial role in affecting the vitality of rental housing markets (Andrew, 2012) and the ensuing severity of rent burden. Metcalf (2018) stated that conceptually housing and labor markets show similar trends. In the American context, ${ }^{9}$ Dwyer and Phillips Lassus (2015) scrutinized both housing and labor markets simultaneously and suggested that labor market insecurity must be considered when studying housing insecurity because the former has a leading role in explaining housing market problems in U.S. cities.

Moreover, in the U.S., there is a group of dense, job-attractive MSAs - the "superstars" 10 of unaffordability-that have considerable economic prosperity

\footnotetext{
$\overline{9}$ We review $U . S$.-focused studies in "Regional economic specialization and rent burden" section because after numerous extensive searches we were not able to find any scholarly effort in English exploring the relationship between regional economic specialization and rent burden in other locations.

10 The examples are San Francisco, New York, and Boston among others.
}

stemming from noticeable specialization, but these metropolises also have unprecedented housing affordability problems (Metcalf, 2018). Besides these unaffordable superstars, "comeback" cities (those experiencing the reversal of the systematic inner-city decline) have also witnessed decreasing housing affordability (Voith \& Wachter, 2009). This reversal causing the inner-city revival could be a potential reason for increased rental demand, rents (Wachter, 2015), and eventually rent burden. Additionally, Voith and Wachter (2009) documented an inherent conflict between urban growth and housing affordability. We theorize that the synergy of these trends (i.e., rising attractiveness due to economic specialization/growth and declining affordability) in certain cities may increase rentership in such locations and resurface rent burden.

Generally, housing prices and rents reflect local economy's vitality-prices tend to rise following job growth and remain static or fall with job losses (Landis et al., 2002). However, the knowledge on how the nature of jobs-economic and occupational specialization-relates to rental housing is difficult to identify. The relationship between regional economic specialization, housing affordability, and rent burden may quite misleadingly seem to be studied sufficiently. As shown below, this specific relationship has not been analyzed systematically within the geography literature, which has also resulted in a lack of consistent scholarship. The identification of this research gap is one of the major contributions of this review article.

Economic specialization and housing affordability

Here we predominantly review relevant articles from a special issue of Housing Policy Debate (HPD). Those several manuscripts, so far, are the only that closely explore how regional economic specialization affects housing affordability, and that is why their perusal has not lost its importance over time. Broadly, this special issue focuses on the relationship between housing markets and the "new economy" (also knowledge/ digital economy; for definition see Landis et al., 2002). For example, Malpezzi (2002) examined factors inflating housing prices in the new economy MSAs, particularly those technology-oriented. He found that regions with established educational systems were more likely to attract high-tech economies, and that 
the housing prices were most affected by regulation and demand-side factors. Malpezzi (2002) suggested that conventional factors (i.e., income, demography, market regulations) were better determinants of increasing housing prices rather than the economy's technological orientation.

Landis et al. (2002) analyzed the interrelations between industrial structure and housing. They found that even though the transformation of U.S. housing markets was caused by the economic restructuring, the relationships between the restructuring and housing markets were not explored systematically, and that the literature linking metropolitan economic structure and housing markets was (and still is) sparse. They also noted that housing in the new economy markets tended to be more expensive, and homeownership rates were lower, whereas overcrowding was higher. The authors concluded that metropolitan industrial structure did affect housing market outcomes, and an increase in housing prices in the new economy markets decreased affordability for low- and moderate-income households, especially renters.

Nelson (2002) studied the U.S. MSAs in terms of shares of high-tech employment to elicit effective lowincome housing strategies given local markets' characteristics. She found that it was more difficult for low-income renters to find affordable housing in hightech metropolises because of shortages in affordable rentals. However, Nelson also concluded that a supply/ demand mismatch was a major culprit for increased housing prices/rents and that the tech-boom exacerbated the problem of housing affordability but did not create it - a finding similar to those in Malpezzi (2002) and Landis et al. (2002).

Quercia et al. (2002) examined the relationship between high-tech economic growth and severe housing problems among moderate-income and working-class households in major American MSAs. They found that the presence of a sizable high-tech sector had aggravated housing affordability problems for both renters and owners. Moreover, having a job did not guarantee decent, affordable housing. They proposed a rectification in housing policy to address the problems of working families, since this low affordability issue was caused by rapid economic growth.

Relatedly, Chapple et al. (2004) scrutinized the impact of sectoral location and employment patterns on housing markets in the Bay Area, California and the Twin Cities, Minnesota. They demonstrated that the presence of start-ups had a measurable positive effect on price appreciation. Referring to the HPD special issue, they claimed that studies had only begun to establish a link between housing price variation and regional specialization.

A similar article on high-tech locations in MSAs (Hackler, 2003) emphasized that in contrast to employees, industries might not find the presence of much affordable (rental) housing to be attractive. Little economic opportunity existed in cities where housing affordability was not a problem; in contrast, less affordable cities were likely to attract high-tech industry growth since they provided economic opportunities for high-tech agglomerations.

\section{Concluding remarks}

Although the cited articles provide valuable insights, rentership in some of them was not studied explicitly and the findings did not link regional economic specialization with rent burden. Moreover, the hightech boom seemed to be a transient flash of the scholarship reviewed in this section. Similar research on both high-tech and regular labor markets with certain specializations have not been updated for quite a while. Even though Landis et al. (2002), Malpezzi (2002), and Nelson (2002) posited that regional economic specialization was not a major cause (but had an effect) for decreasing affordability and increasing rent burden, more research for generalization and updates are needed. After almost two decades with one recession during 2008-2009, the situation might have changed, with inter-regional migrations occurring from the expensive, rent-burdened locations of the high-tech corridors in the Bay Area toward the Sunbelt (e.g., Texas and Arizona). ${ }^{11}$ We believe this new trend might initiate a different type of rental crises/break-up in the tech-corridor of the Bay Area. How might these related factors of regional economic specializations and acts of (dis)balancing impact rent burden across the U.S.? All such issues need a renewed focus with an expanded geographical coverage, while linking

\footnotetext{
$\overline{11}$ Recently, the co-author's interactions with numerous California transplants in the metropolises of Texas (Austin, Dallas) and Arizona (Tucson) suggest that the unaffordable housing markets in the high-tech corridor of the Bay Area is being challenged by simultaneous growth and attractiveness of the evolving technology corridor in Texas and Arizona which have more affordable housing.
} 
(sub)regional economic specializations with rental markets and rent burden. The availability of data on housing and labor markets at granular scales offer possibilities to model spatial relationships between housing affordability and labor markets (Andrew, 2012).

\section{Conclusions}

Rental accommodations house more than a billion tenants around the globe and in some countries rentership has been increasing in recent years. Given this extent of rental housing and a somewhat lopsided focus of policy (and scholarship to some degree) towards homeownership, it is critical to pay attention to rentership and related issues such as rental affordability and rent burden through a geographic lens. Currently, most reviewed scholarly works pertaining to the nexus of rentership, affordability, and rent burden belong to such fields as public policy, economics, sociology, and urban planning. Nevertheless, there are significant and discernible directions for geographers to contribute toward a nuanced understanding of rent burden by spatially examining the nexus of regional economic specialization and labor/ demographic characteristics in terms of human capital. Such analysis will produce more generalizable knowledge by examining rent burden in various settings.

In this review of academic literature, we have identified and discussed four major themes in the recent interdisciplinary research at the intersection of rentership, affordability, and rent burden. While amalgamating major (sub)themes and identifying missing links, we emphasize the importance of geographical perspectives and spatiality which are lacking in a substantial share of the reviewed scholarship. In each of the four themes, we pinpoint major shortcomings and gaps in the literature on rentership. These are provided in the last subheadings of each section and we encourage looking at those concluding remarks in a focused manner. Such remarks include, for example, the expansion of the geographic scope of rental housing financialization due to its spillover to the Global South; a lack of incorporation between the rental housing financialization scholarship and the scholarship examining the growing number of U.S. single-family rentals (and a subsequent increase in investor activity regarding this type of rental housing).
Studying in conjunction those processes affecting housing affordability would bring some requisite insights on rent burden and those insights could be helpful in addressing this issue by appropriate policy interventions.

As to the most apparent future pathways for research, these include more comparative studies on rental housing financialization which can also contrast it with similar processes observed with U.S. singlefamily rentals. The next major suggestion is studying rent burden holistically through a geographic lens which is essential given how this line of research is, in fact, relatively scanty and disjointed in itself. Additionally, the knowledge on how regional economic specialization affects local rental markets and rent burden is lacking in the recent scholarship, and this gap is the most evident one (see "Regional economic specialization and rent burden" section) which requires a timely scholarly inquiry.

Finally, given the identified contexts of asset accumulation and profit extraction caused by rental housing financialization and increasing rent burden in many locations, it is becoming more difficult to establish or normalize housing as a right. Moreover, the notion of housing as a right tends to favor homeownership which, however, may be often unattainable for low-income and increasingly middle-income households (Rolnik, 2013). The political normalization of tenure diversity (Wegmann et al., 2017) is needed, and hence, it is critical to explicitly incorporate rentership into the 'housing as a right' literature within geography and other disciplines.

Funding This work was supported by the Scholarly Activity and Research Incentive Funds (SARIF), Office of Research \& Engagement, University of Tennessee, Knoxville.

\section{References}

Aalbers, M. B. (2017). The variegated financialization of housing. International Journal of Urban and Regional Research, 41(4), 542-554

Aalbers, M. B. (2020). Financial geography III: The financialization of the city. Progress in Human Geography, 44(3), 595-607

Aalbers, M. B., Loon, J. V., \& Fernandez, R. (2017). The financialization of a social housing provider. International Journal of Urban and Regional Research, 41(4), 572-587

Andrew, M. (2012). Regional market size and the housing market: insights from a new economic geography model. Journal of Property Research, 29(4), 298-323 
Aratani, Y., Chau, M. M., Wight, V., \& Addy, S. D. (2011). Rent burden, housing subsidies and the well-being of children and youth.

Arnott, R. (2008). Housing policy in developing countries: The importance of the informal economy. Urbanization and Growth 167.

August, M. (2020). The financialization of Canadian multifamily rental housing: From trailer to tower. Journal of Urban Affairs, 42(7), 975-997. https://doi.org/10.1080/ 07352166.2019 .1705846

August, M., \& Walks, A. (2018). Gentrification, suburban decline, and the financialization of multi-family rental housing: The case of Toronto. Geoforum, 89, 124-136

Backhaus, T., Gebers, K., \& Schröder, C. (2015) Evolution and determinants of rent burdens in Germany. SOEP Paper (806).

Baker, E., Bentley, R., Lester, L., \& Beer, A. (2016). Housing affordability and residential mobility as drivers of locational inequality. Applied Geography, 72, 65-75

Ballesteros, M. M. (2004). Rental housing for urban low-income households in the Philippines (No. 2004-47) PIDS Discussion Paper Series.

Bean, J. A. (2012). Renters more often burdened by housing costs after recession: Nearly half of all renters spent over 30 percent of income on housing by 2010 .

Beer, A. (1999). Housing investment and the private rental sector in Australia. Urban Studies, 36(2), 255-269

Beer, C., \& Wagner, K. (2012). Housing cost burden of Austrian households: Results of a recent survey. Monetary Policy and the Economy, 4, 78-89

Beitel, K. (2007). Did overzealous activists destroy housing affordability in San Francisco? A time-series test of the effects of rezoning on construction and home prices, 1967-1998. Urban Affairs Review, 42(5), 741-756

Bogdon, A. S., \& Can, A. (1997). Indicators of local housing affordability: Comparative and spatial approaches. Real Estate Economics, 25(1), 43-80

Bonds, A. (2019). Race and ethnicity I: Property, race, and the carceral state. Progress in Human Geography, 43(3), 574-583

Bourassa, S., Hoesli, M., \& Scognamiglio, D. (2010). Housing finance, prices, and tenure in Switzerland. Journal of Real Estate Literature, 18(2), 261-282

Bramley, G. (2012). Affordability, poverty and housing need: Triangulating measures and standards. Journal of Housing and the Built Environment, 27(2), 133-151

Bunting, T., Walks, A. R., \& Filion, P. (2004). The uneven geography of housing affordability stress in Canadian metropolitan areas. Housing Studies, 19(3), 361-393

Byrne, M. (2020). Generation rent and the financialization of housing: A comparative exploration of the growth of the private rental sector in Ireland, the UK and Spain. Housing Studies, 35(4), 743-765

Cadstedt, J. (2010). Private rental housing in Tanzania-a private matter? Habitat International, 34(1), 46-52

Carpenter, A., White, D., \& Hirt, M. (2018). Rental housing affordability in the Southeast: Data from the sixth district. FRB Atlanta Community and Economic Development Discussion Paper (2018-2).

Chapple, K., Thomas, J. V., Belzer, D., \& Autler, G. (2004). Fueling the fire: Information technology and housing price appreciation in the San Francisco Bay area and the Twin Cities. Housing Policy Debate, 15(2), 347-383

Charette, A., Herbert, C., Jakabovics, A., Marya, E. T., \& McCue, D. T. (2015). Projecting trends in severely costburdened renters: 2015-2025. Harvard University's Joint Center for Housing Studies and Enterprise Community Partners Inc.

Chen, Y., Liu, X., Li, X., Liu, Y., \& Xu, X. (2016). Mapping the fine-scale spatial pattern of housing rent in the metropolitan area by using online rental listings and ensemble learning. Applied Geography, 75, 200-212

Chi, P. S., \& Laquatra, J. (1998). Profiles of housing cost burden in the United States. Journal of Family and Economic Issues, 19(2), 175-193

Chilton, K., Silverman, R. M., Chaudhry, R., \& Wang, C. (2018). The impact of single-family rental REITs on regional housing markets: A case study of Nashville, TN. Societies, 8(4), 93

Colburn, G., \& Allen, R. (2018). Rent burden and the Great Recession in the USA. Urban Studies, 55(1), 226-243

Colburn, G., Walter, R. J., \& Pfeiffer, D. (2020). Capitalizing on collapse: An analysis of institutional single-family rental investors. Urban Affairs Review. https://doi.org/10.1177/ 1078087420922910

Coley, R. L., Kull, M., Leventhal, T., \& Lynch, A. D. (2014). Profiles of housing and neighborhood contexts among lowincome families: Links with children's well-being. $\mathrm{Ci}$ tyscape, 16(1), 37-60

Collinson, R. (2011). Rental housing affordability dynamics, 1990-2009. Cityscape, 13(2), 71-103

Crosby, A. (2020). Financialized gentrification, demoviction, and landlord tactics to demobilize tenant organizing. $\mathrm{Ge}$ oforum, 108, 184-193

Daniel, L., Baker, E., \& Lester, L. (2018). Measuring housing affordability stress: can deprivation capture risk made real? Urban Policy and Research, 36(3), 271-286

Datta, K., \& Jones, G. A. (2001). Housing and finance in developing countries: invisible issues on research and policy agendas. Habitat International, 25(3), 333-357

Dawkins, C., \& Jeon, J. S. (2018). Housing cost burden in the housing choice voucher program: The impact of HUD program rules. Cityscape, 20(1), 39-62

Deidda, M. (2015). Economic hardship, housing cost burden and tenure status: Evidence from EU-SILC. Journal of Family and Economic Issues, 36(4), 531-556

Desmond, M. (2018). Heavy is the house: Rent burden among the American Urban Poor. International Journal of Urban and Regional Research, 42(1), 160-170

Desmond, M., \& Shollenberger, T. (2015). Forced displacement from rental housing: Prevalence and neighborhood consequences. Demography, 52(5), 1751-1772

DeVaney, S. A., Chiremba, S., \& Vincent, A. M. (2004). Life cycle stage and housing cost burden. Journal of Financial Counseling and Planning, 15(1), 31-39

Dong, H. (2018). The impact of income inequality on rental affordability: An empirical study in large American metropolitan areas. Urban Studies, 55(10), 2106-2122

Dwyer, R. E., \& Phillips Lassus, L. A. (2015). The great risk shift and precarity in the US housing market. The Annals of the American Academy of Political and Social Science, 660(1), 199-216 
Edmiston, K. D. (2016). Residential rent affordability across US metropolitan areas. (pp. 5-27). Federal Reserve Bank of Kansas City Economic Review.

Eggers, F. J. (2010). Investigating very high rent burdens among renters in the American Housing Survey. DIANE Publishing.

Ellen, I. G., \& Karfunkel, B. (2016). Renting in America's largest metropolitan areas. National Affordable Rental Housing Landscape.

Elmelech, Y. (2004). Housing inequality in New York City: Racial and ethnic disparities in homeownership and shelter-cost burden. Housing, Theory and Society, 21(4), $163-175$

Fernandez, R., \& Aalbers, M. B. (2020). Housing financialization in the Global South: In search of a comparative framework. Housing Policy Debate, 30(4), 680-701

Fields, D. (2015). Contesting the financialization of urban space: Community organizations and the struggle to preserve affordable rental housing in New York City. Journal of Urban Affairs, 37(2), 144-165

Fields, D. (2017). Unwilling subjects of financialization. International Journal of Urban and Regional Research, 41(4), 588-603

Fields, D. J., Kohli, R., \& Schafran, A. (2016). The emerging economic geography of single-family rental securitization. Federal Reserve Bank of San Francisco.

Fields, D., \& Uffer, S. (2016). The financialisation of rental housing: A comparative analysis of New York City and Berlin. Urban Studies, 53(7), 1486-1502

Gabriel, S., \& Painter, G. (2020). Why affordability matters. Regional Science and Urban Economics, 8, 103378

Garboden, P. M., \& Newman, S. (2012). Is preserving small, low-end rental housing feasible? Housing Policy Debate, 22(4), 507-526

Gilbert, A. (2016). Rental housing: The international experience. Habitat International, 54, 173-181

Glaeser, E. L., \& Gyourko, J. (2002). The impact of zoning on housing affordability (No. w8835) National Bureau of Economic Research.

Goodman, A. C., \& Kawai, M. (1984). Estimation and policy implications of rental housing demand. Journal of Urban Economics, 16(1), 76-90

Greulich, E., Quigley, J. M., Raphael, S., Tracy, J., \& Jasso, G. (2004). The anatomy of rent burdens: Immigration, growth, and rental housing. Brookings-Wharton Papers on Urban Affairs 149-205.

Hackler, D. (2003). High-tech location in five metropolitan areas. Journal of Urban Affairs, 25(5), 625-640

Hochstenbach, C. (2017). State-led gentrification and the changing geography of market-oriented housing policies. Housing, Theory and Society, 34(4), 399-419

Houston, D., \& Sissons, P. (2012). The changing geography of privately rented housing in England and Wales. Urban Studies, 49(4), 795-819

Hu, L., He, S., Han, Z., Xiao, H., Su, S., Weng, M., \& Cai, Z. (2019). Monitoring housing rental prices based on social media: An integrated approach of machine-learning algorithms and hedonic modeling to inform equitable housing policies. Land Use Policy, 82, 657-673
Hulchanski, J. D. (1995). The concept of housing affordability: Six contemporary uses of the housing expenditure-to-income ratio. Housing Studies, 10(4), 471-491

Immergluck, D. (2018). Renting the dream: The rise of singlefamily rentership in the Sunbelt Metropolis. Housing Policy Debate, 28(5), 814-829

Immergluck, D., Carpenter, A., \& Lueders, A. (2016). Declines in low-cost rented housing units in eight large southeastern cities. FRB Atlanta Community and Economic Development Discussion Paper (2016-3).

Immergluck, D., Carpenter, A., \& Lueders, A. (2018). Hot city, cool city: explaining neighbourhood-level losses in lowcost rental housing in southern US cities. International Journal of Housing Policy, 18(3), 454-478

Immergluck, D., \& Law, J. (2014a). Investing in crisis: The methods, strategies, and expectations of investors in singlefamily foreclosed homes in distressed neighborhoods. Housing Policy Debate, 24(3), 568-593

Immergluck, D., \& Law, J. (2014b). Speculating in crisis: The intrametropolitan geography of investing in foreclosed homes in Atlanta. Urban Geography, 35(1), 1-24

Joice, P. (2014). Measuring housing affordability. Cityscape, 16(1), 299-308

Koebel, C. T. (1997). Housing conditions of low-income families in the private, unassisted housing market in the United States. Housing Studies, 12(2), 201-213

Kumar, S. (2011). The research-policy dialectic: A critical reflection on the virility of landlord-tenant research and the impotence of rental housing policy formulation in the urban Global South. City, 15(6), 662-673

Kutty, N. K. (2005). A new measure of housing affordability: Estimates and analytical results. Housing Policy Debate, 16(1), 113-142

Kutz, W. (2018). Financialization interrupted: Unwilling subjects of housing reform in Morocco. City, 22(4), 568-583

Kutz, W., \& Lenhardt, J. (2016). "Where to put the spare cash?" Subprime urbanization and the geographies of the financial crisis in the Global South. Urban Geography, 37(6), 926-948

Landis, J. D., Elmer, V., \& Zook, M. (2002). New economy housing markets: Fast and furious-but different? Housing Policy Debate, 13(2), 233-274

Landis, J. D., \& McClure, K. (2010). Rethinking federal housing policy. Journal of the American Planning Association, 76(3), 319-348

Lee, S. W., \& Myers, D. (2003). Local housing-market effects on tenure choice. Journal of Housing and the Built Environment, 18(2), 129-157

Lens, M. C. (2018). Extremely low-income households, housing affordability and the Great Recession. Urban Studies, 55(8), 1615-1635

Leopold, J., Getsinger, L., Blumenthal, P., Abazajian, K., \& Jordan, R. (2015). The housing affordability gap for extremely low-income renters in 2013. Urban Institute.

Leventhal, T., \& Newman, S. (2010). Housing and child development. Children and Youth Services Review, 32(9), 1165-1174

Liu, Y., Cheshire, L., \& Wadley, D. (2016). Mapping mis-location and housing stress in the private rental sector: A case study of Brisbane, Australia. Applied Geography, 76, 207-216 
Liu, R., Li, T., \& Greene, R. (2020). Migration and inequality in rental housing: Affordability stress in the Chinese cities. Applied Geography. https://doi.org/10.1016/j.apgeog. 2019.102138

McClure, K. (2005). Rent burden in the housing choice voucher program. Cityscape, 8(2), 5-20

McConnell, E. D. (2013). Who has housing affordability problems? Disparities in housing cost burden by race, nativity, and legal status in Los Angeles. Race and Social Problems, 5(3), 173-190

McConnell, E. D., \& Akresh, I. R. (2010). Housing cost burden and new lawful immigrants in the United States. Population Research and Policy Review, 29(2), 143-171

McKee, K. (2012). Young people, homeownership and future welfare. Housing Studies, 27(6), 853-862

Malpezzi, S. (2002). Urban regulation, the "new economy", and housing prices. Housing Policy Debate, 13(2), 323-349

Malpezzi, S., \& Green, R. K. (1996). What has happened to the bottom of the US Housing Market? Urban Studies, 33(10), $1807-1820$

Mast, B. (2014). Markov chain model of rent burden in the housing choice voucher program. Journal of Housing Research, 23(2), 177-202

Matlack, J. L., \& Vigdor, J. L. (2008). Do rising tides lift all prices? Income inequality and housing affordability. Journal of Housing Economics, 17(3), 212-224

Meltzer, R., \& Schwartz, A. (2016). Housing affordability and health: evidence from New York City. Housing Policy Debate, 26(1), 80-104

Mendenhall, R., Kramer, K. Z., \& Akresh, I. R. (2014). Asset accumulation and housing cost burden: Pathways to (not) saving. Housing Policy Debate, 24(2), 387-414

Metcalf, G. (2018). Sand castles before the tide? Affordable housing in expensive cities. Journal of Economic Perspectives, 32(1), 59-80

Migozzi, J. (2020). Selecting spaces, classifying people: The financialization of housing in the South African City. Housing Policy Debate, 30(4), 640-660

Mimura, Y. (2008). Housing cost burden, poverty status, and economic hardship among low-income families. Journal of Family and Economic Issues, 29(1), 152-165

Moore, E., \& Skaburskis, A. (2004). Canada's increasing housing affordability burdens. Housing Studies, 19(3), 395-413

Nelson, K. P. (2002). Housing needs and effective policies in high-tech metropolitan economies. Housing Policy Debate, 13(2), 417-468

Nelson, S., Delgadillo, L., \& Dew, J. P. (2013). Housing cost burden and marital satisfaction. Marriage and Family Review, 49(6), 546-561

Newman, S. J., \& Holupka, C. S. (2014). Housing affordability and investments in children. Journal of Housing Economics, 24, 89-100

Newman, S. J., \& Holupka, C. S. (2015). Housing affordability and child well-being. Housing Policy Debate, 25(1), 116-151

O'Regan, K. M., \& Horn, K. M. (2013). What can we learn about the low-income housing tax credit program by looking at the tenants? Housing Policy Debate, 23(3), 597-613
Oh, D. H. (1995). Households with rent burdens: Impact on other spending and factors related to the probability of having a rent burden. Journal of Financial Counseling and Planning, 6, 139-147

Pfeiffer, D., \& Lucio, J. (2015). An unexpected geography of opportunity in the wake of the foreclosure crisis: low-income renters in investor-purchased foreclosures in Phoenix, Arizona. Urban Geography, 36(8), 1197-1220

Pfeiffer, D., Schafran, A., \& Wegmann, J. (2020). Vulnerability and opportunity: Making sense of the rise in single-family rentals in US neighbourhoods. Housing Studies. https://doi. org/10.1080/02673037.2020.1739235

Quercia, R. G., Stegman, M. A., \& Davis, W. R. (2002). Does a high-tech boom worsen housing problems for working families? Housing Policy Debate, 13(2), 393-415

Radzimski, A. (2014). Subsidized mortgage loans and housing affordability in Poland. GeoJournal, 79(4), 467-494

Rahman, A., \& Harding, A. (2014). Spatial analysis of housing stress estimation in Australia with statistical validation. Australasian Journal of Regional Studies, 20(3), 452-486

Rakodi, C. (1995). Rental tenure in the cities of developing countries. Urban Studies, 32(4-5), 791-811

Ray, R., Ong, P., \& Jimenez, S. (2014). Impacts of the Widening Divide: Los Angeles at the forefront of the rent burden crisis. UCLA Luskin School of Public Affairs.

Rolnik, R. (2013). Late neoliberalism: The financialization of homeownership and housing rights. International Journal of Urban and Regional Research, 37(3), 1058-1066

Salinas, A. L., \& Teixeira, C. (2020). Settlement and housing experiences of recent Mexican immigrants in Vancouver suburbs. GeoJournal 1-26.

Sanfelici, D., \& Halbert, L. (2019). Financial market actors as urban policy-makers: the case of real estate investment trusts in Brazil. Urban Geography, 40(1), 83-103

Savini, F., Boterman, W. R., Van Gent, W. P., \& Majoor, S. (2016). Amsterdam in the 21st century: Geography, housing, spatial development and politics. Cities, 52, 103-113

Scally, C. P. (2013). The nuances of NIMBY: Context and perceptions of affordable rental housing development. Urban Affairs Review, 49(5), 718-747

Schuetz, J. (2009). No renters in my suburban backyard: Land use regulation and rental housing. Journal of Policy Analysis and Management, 28(2), 296-320

Soederberg, S. (2018). The rental housing question: Exploitation, eviction and erasures. Geoforum, 89, 114-123

Steinführer, A., \& Haase, A. (2009). Flexible-inflexible: sociodemographic, spatial and temporal dimensions of flat sharing in Leipzig (Germany). GeoJournal, 74(6), 567-587

Stockman, P. K. (1992). Anti-snob zoning in Massachusetts: Assessing one attempt at opening the suburbs to affordable housing. Virginia Law Review, 78(2), 535-580

Sunega, P., \& Lux, M. (2016). Subjective perception versus objective indicators of overcrowding and housing affordability. Journal of Housing and the Built Environment, 31(4), 695-717

Susin, S. (2007). Duration of rent burden as a measure of need. Cityscape, 9(1), 157-174

Tanton, R., \& Phillips, B. (2013). A measure of the depth of housing stress and its application in Australia. Economic 
Papers: A Journal of Applied Economics and Policy, 32(1), 99-109

Tapp, R. (2019). Renters' revolt: Revisiting City of Quartz to understand Los Angeles's housing crisis. City, 23(1), $123-127$

Teater, B. (2009). Factors predicting residential mobility among the recipients of the Section 8 Housing Choice Voucher Program. Journal of Sociology \& Social Welfare, 36(3), 159-178

Teresa, B. F. (2016). Managing fictitious capital: The legal geography of investment and political struggle in rental housing in New York City. Environment and Planning A: Economy and Space, 48(3), 465-484

Turk, M. (2004). The question of rent: the emerging urban housing crisis in the new century. International Journal of Urban and Regional Research, 28(4), 909-918

Unger, K. (2016). Financialization of mass rental housing in Germany: Understanding the transaction cycles in the mass rental housing sector 1999-2015. Barbara Schönig/Sebastian Schipper (Hg.): Urban Austerity: Impacts of the Global Financial Crisis on Cities in Europe. Berlin: Theater der Zeit 176-190.

Voith, R. P., \& Wachter, S. M. (2009). Urban growth and housing affordability: The conflict. The Annals of the American Academy of Political and Social Science, 626(1), 112-131

Wachter, S. (2015). Housing America: The unequal geography of risk and opportunity. Housing Policy Debate, 25(4), 813-816
Waldron, R. (2018). Capitalizing on the state: The political economy of real estate investment trusts and the 'resolution' of the crisis. Geoforum, 90, 206-218

Wegmann, J., Schafran, A., \& Pfeiffer, D. (2017). Breaking the double impasse: Securing and supporting diverse housing tenures in the United States. Housing Policy Debate, 27(2), 193-216

Wijburg, G. (2020). The de-financialization of housing: towards a research agenda. Housing Studies. https://doi.org/10. 1080/02673037.2020.1762847

Wijburg, G., Aalbers, M. B., \& Heeg, S. (2018). The financialisation of rental housing 2.0: Releasing housing into the privatised mainstream of capital accumulation. Antipode, 50(4), 1098-1119

Williamson, A. R. (2011). Can they afford the rent? Resident cost burden in low income housing tax credit developments. Urban Affairs Review, 47(6), 775-799

Withers, S. D. (1997). Demographic polarization of housing affordability in six major United States metropolitan areas. Urban Geography, 18(4), 296-323

Yates, J., \& Wulff, M. (2005). Market provision of affordable rental housing: lessons from recent trends in Australia. Urban Policy and Research, 23(1), 5-19

Publisher's Note Springer Nature remains neutral with regard to jurisdictional claims in published maps and institutional affiliations. 